Nataša Kožul

Samostalni ekspert i konsultant za investiciono bankarstvo nkozul@gmail.com

Originalna verzija

teksta je na

engleskom jeziku

Prevod

obezbedio

autor
POSLEDICE PORASTA KAMATNIH STOPA U SAD NA GLOBALNO FX TRŽIŠTE

\title{
Rezime
}

Nakon globalne finansijske krize koja je počela 2008. godine, kamatne stope su smanjene u mnogim državama, da bi se stimulisao ekonomski rast, ali i umanjio rizik neisplate postojećih dugovanja. Niske kamatne stope smanjuju motivaciju za štednju, što navodi potrošače da ulažu sredstva u imovinu, kao što su nekretnine, tako neposredno podstičući porast bogatstva. Takođe, pošto one čine valutu jeftinijom na međunarodnom tržištu, izvozna roba postaje kompetitivnija, dok se smanjuje inostrana potražnja za dugovanjima u datoj valuti. Svi ovi faktori bi trebalo da stimulišu ekonomiju, ali je njihova posledica i smanjena kompetitivnost na svetskom finansijskom tržištu, gde je dobit ostvarena na ulog prvenstveno uslovljena preovladavajućim kamatnim stopama. Niske kamatne stope takođe podstiču veće zaduživanje, koje postaje neodrživo kada dođe do njihovog porasta. Osim toga, investitori koji u velikoj meri ovise o kamatnim stopama kao izvoru prihoda će potencijalno tražiti spekulativnija i rizičnija ulaganja, što može dovesti do značajnih gubitaka. Konačno, pošto se tržišna kamatna stopa sastoji od realne stope i inflacije, njeno smanjenje menja ravnotežu u ovoj vezi, što može dovesti do inflatorne ekonomije. Sada kada su u SAD povećane domaće kamatne stope po prvi put od 2006. godine, važno je ispitati potencijalne posledice koje će to imati na svetsko tržište i ekonomiju drugih država. Ovaj rad nudi neke uvide u dinamiku FX tržišta i objašnjava zašto kamatna stopa u SAD ima svetski značaj.

Ključne reci: kamatne stope $S A D$, inflacija, kursna razlika, kursna razlika za budući period, trenutna kursna razlika, trgovinski bilans, svetska ekonomija

JEL: O31, O32, G21 


\section{EFFECTS OF RAISING US INTEREST RATES ON GLOBAL FX MARKETS}

Nataša Kožul

Independent expert and investment banking consultant nkozul@gmail.com
The original version of the text is in English

Translation provided by the author

\section{Summary}

Following the global financial crisis of 2008, many countries decreased their domestic interest rates as a means of stimulating economic growth, while also providing protection from substantial default on debt. Low interest rates reduce the incentive to save, prompting consumers to purchase assets, such as housing, thus implicitly increasing wealth. In addition, they make the currency relatively cheaper, making exports more competitive, while reducing foreign demand for holding debt in that currency. All these should stimulate economy, albeit at the cost of reduced competitiveness in the world financial markets, where return on investment is largely determined by the interest rates. Low interest rates also prompt greater borrowing, which may not be sustainable once they start to rise. In addition, those that largely depend on interest rate income may seek more speculative and high-risk investments, potentially leading to significant defaults. Finally, as the market interest rate is composed of the real rate and inflation, decreasing rates changes the balance in this relationship, which may lead to inflationary economy. Now that the US has increased its domestic rates for the first time since 2006, it is important to examine the potential effects this will have on global markets and other economies. This paper offers some insights into the dynamics of the FX markets and discusses why the US rate is so closely watched worldwide.

Keywords: US interest rates, inflation, FX rate, forward exchange rate, spot exchange rate, trade balance, global economy

JEL: O31, O32, G21 


\section{Uvod}

Devizni kurs je odnos dve valute koji je ključan u nivou trgovine koji neka zemlja može da ostvari, jer određuje cene uvozne i izvozne robe, pa tako i uspeh domaće ekonomije. Devizni kursevi za duže periode su takođe uslovljene kamatnim stopama i inflacijom u datim državama, što ih čini jednim od najvažnijih ekonomskih varijabli za praćenje i analizu, kao i manipulaciju od strane vlada (Patel, Patel, \& Patel, 2014). Uvažavajući njihov značaj za globalno finansijsko tržište, one takođe imaju veliki uticaj i na mnogo osnovnijem nivou, pošto određuju cenu zaduživanja i pozajmica na internacionalnom tržištu, što utiče na raspoloživost sredstava u domaćem sektoru. Stoga one imaju ulogu i $\mathrm{u}$ individualnom nivou bogatstva, kao i obrascima potrošnje. Ovo, pak, utiče na cenu i dostupnost roba i usluga, kao i profitabilnost različitih oblika ulaganja, koji su implicitno uslovljeni kvalitetom domaće ekonomije i trgovinskih odnosa zemlje s drugim državama. Ovaj ciklični i uzajamno povezani proces je pod uticajem mnogih faktora, uključujući i kamatne stope (Bilson, 1978). Valuta veće vrednosti čini izvoz skupljim na stranim tržištima, a uvoz jeftinijim i obratno. Tako, više kamatne stope umanjuju trgovinski bilans države. Pre prelaska na analizu glavnih odrednica kamatne stope $u$ daljem tekstu, nude se neke osnovne relacije u njihovom izračunavanju.

\section{Izračunavanje deviznih kurseva}

Kursna razlika odnosi se na razmenu jedne valute za drugu. Predstavlja se u obliku CCY $/$ $\mathrm{CCY}_{2}$, što označava "osnovnu", odnosno "varijabilnu" valutu (Kožul, 2011). Njena vrednost ukazuje na to koliko se varijabilne valute plati/dobije za jedinicu osnovne valute. Na domaćem tržištu, osnovna valuta je domaća valuta, dok je na međunarodnim tržištima to tipično američki dolar (USD), iako se, od njegovog uvođenja, sve češće kvote za različite valute daju u odnosu na euro (EUR). Kada se govori o kursnoj razlici, bitno je napraviti razliku između spot (za ugovore sa trenutnim izvršenjem) i terminskih stopa (koje se odnose na ugovore sa različitim trajanjima).

\section{Spot kursna razlika (Spot Rate)}

Spot devizni kurs se odnosi na ugovore izvršene odmah. Na finansijskim tržištima, dostava je obično dva radna dana od datuma trgovanja kako bi se omogućile potrebne bankovne transakcije i dostava dokumentacije, kao i uzeli u obzir praznici u datim državama. Iako se može trgovati bilo kojom kombinacijom valuta, većina kvota je data u odnosu na EUR (interbank spot market), ili USD (futures market), koje se nazivaju direktne stope (direct rates).

Drugi valutni parovi tako indirektno uključuju kalkulaciju stopa u odnosu na USD ili EUR, pa se nazivaju indirektne stope (cross-rates). Na primer, da bi se dobila vrednost CHF/CAD kursne razlike, prvo je potrebno izračunati količinu USD dobijenih po prodaji CHF, a zatim vrednost CAD koji se mogu kupiti za gore dobijene USD, što rezultira u efektivnoj CHF/ CAD stopi. Kako indirektne kursne razlike uključuju istovremenu kupovinu i prodaju, na njih utiču promene tri valute. Budući da učesnici na finansijskom tržištu ostvaruju profit tako što kupuju po nižoj ceni, a prodaju po višoj, svaka kursna razlika ima dve vrednosti, što dovodi do bid/offer spread-a, čija je širina određena dinamikom ponude i tražnje. Razlika između "gornjeg" i "donjeg" kursa je uglavnom mala za glavne svetske valute, dok postaje znatno šira za one koje se računaju indirektno, jer se mora uzeti u obzir niža likvidnost kao i implicirana kupovina/prodaja osnovne valute.

\section{Kursne razlike za periode $\mathbf{u}$ budućnosti (Forward Cross-Currency Contracts)}

Devizni kurs za periode u budućnosti (forward cross-currency contracts) uključuje kupovinu ili prodaju jedne valute u zamenu za drugu valutu, čija će se realizacija odigrati u budućnosti. I u ovom slučaju važe gore navedena pravila o izračunavanju kursnih razlika, tj. postoji "gornji" i "donji" kurs, po kome se prodaje/kupuje valuta. Kod parova koji uključuju glavne svetske valute, svi novčani tokovi se razmenjuju po dospeću, dok se ugovori po nekim manje likvidnim valutama realizuju isplaćivanjem razlika između ugovorene stope i preovladavajuće kursne razlike na dan isteka 


\section{Introduction}

Exchange rate is a ratio between two currencies and is instrumental in the level of trade a country is able to achieve, as it affects the import and export prices, and thus the health of domestic economy. Exchange rates for longer maturities are also influenced by the interest rates and inflation in the respective countries, making them one of the most closely monitored, analyzed and governmentally manipulated economic measures (Patel, Patel, \& Patel, 2014). Their importance to the world markets notwithstanding, exchange rates also have significant impact on a smaller scale, as they affect the cost of lending and borrowing in international markets, affecting the amount of funding available at the domestic level. Thus, they also play a role in the level of individual wealth and consumer spending patterns. This, in turn, is affected by the price and availability of goods and services, as well as profitability of various forms of investment. These are implicitly conditioned by the health of the domestic economy and the country's trading relationships with other nations. This cyclical and interrelated process is affected by many factors, including exchange rates (Bilson, 1978). A more valuable currency makes a country's exports more expensive in foreign markets, while making imports cheaper and vice versa. Thus, higher exchange rate typically lowers the country's trade balance. Before analyzing the main determinants of exchange rates in the sections that follow, some fundamentals in their calculation are offered.

\section{Calculation of Exchange Rates}

Foreign exchange refers to the exchange of one currency for another. It is written in the form $\mathrm{CCY}_{1} / \mathrm{CCY}_{2}$, referred to as "base currency" "variable currency", respectively (Kožul, 2011). Its value refers to how much of variable currency is paid/received for one unit of base currency. In domestic markets, the base currency is the domestic currency, whilst in international markets it is typically USD, even though various currencies are have been quoted against EUR since its introduction. When discussing exchange rates, it is essential to make the distinction between spot rates (for contracts executed now) and forward rates (applicable to various durations).

\section{Spot Exchange Rates}

Spot exchange rates apply to trades executed now. In financial markets, the delivery is typically two working days from the trade date to allow for necessary bank transfers and paperwork, as well as adjust for holidays in both countries. While any currency pair can be traded, most currencies are quoted either against EUR (Interbank spot market), or USD (Futures market), referred to as direct rate.

Other currency combinations have to be calculated from two rates against USD or EUR and are called cross-rates. For example to obtain $\mathrm{CHF} / \mathrm{CAD}$ exchange rate, the amount of USD received on sale of $\mathrm{CHF}$ would be calculated first, and then the amount of CAD purchased by USD would imply the CHF/CAD rate. As cross-rates involve both sale and purchase, they are affected by the dynamics of three currencies. Given that traders make profit from buying/ bidding "low" and selling/offering "high", each exchange rate has two sides, creating bid/offer spread, the width of which is effected by supply and demand. It is typically very tight for major currencies, whilst for currencies quoted as cross rates it is wider, accounting for lower liquidity and the implied intermediate sale/purchase of base currency.

\section{Forward Exchange Rates}

Forward cross-currency contracts involve outright purchase or sale of one currency in exchange for another currency for settlement in the future. The same rules of exchange rate calculations apply, i.e., there is two-way price where sale is made using bid and purchase using offer quotation. In major currency pairs, the two cashflows are exchanged at maturity, whilst in some less liquid contracts only the difference between the agreed rate and the prevailing market exchange rate is settled. The pricing of forward contract in both cases is the same. The main motivation behind such trades is fixing the rate for a time period in the future. As forward cross-currency contract 
ugovora. U oba slučaja, izračunavanje vrednosti forvard ugovora je isto. Glavna motivacija iza takvih transakcija je fiksiranje stope za neki period u budućnosti. Kako na vrednost deviznog kursa u budućim periodima utiče ne samo odnos dve valute, nego i kamatne stope u datim državama, ona se izračunava kao odnos između varijabilne i osnovne valute koji bi bio ostvaren na dan isteka ugovora ako su obe bile stavljene na štednju po kamatnim stopama za isti period, tj.:

$$
F X_{f}=F X_{s} \times \frac{1+r_{v} \times \frac{\text { days }}{\text { year }}}{1+r_{b} \times \frac{\text { days }}{\text { year }}}
$$

gde je:

$F X_{f}$ kursna razlika za period u budućnosti

$F X_{s}$ spot kursna razlika

$r_{v}$ kamatna stopa za varijabilnu valutu

$r_{b}$ kamatna stopa za osnovnu valutu

\section{Svopovi valuta za periode $\mathbf{u}$ budućnosti (Forward Cross-Currency Swaps)}

Kako se može videti iz gore navedenog, terminske međuvalutne transakcije omogućavaju ugovornim stranama da uzmu poziciju vezanu za odnos kamatnih stopa ostvarivih na valute koje su uključene $\mathrm{u}$ razmenu, bez direktnog učešća na kamatnom tržištu. Vrlo česta alternativa je trenutna kupovina/prodaja jedne od valuta (po spot kursnoj razlici) i ulazak u suprotnu transakciju (prodajom/kupovinom iste valute) po forvard stopi. To se na tržištu naziva forward swap (terminski svop). Kako je originalna razmena ostvarena po spot ceni, a po isteku ugovora, transakcija se obavlja po forvard ceni, da bi se izbegla mogućnost arbitraže, vrednost ugovora mora da se izračuna kao razlika između odgovarajućih kursnih razlika, ili:

$$
F S=F X_{f}-F X_{s}=F X_{s} \times \frac{r_{v} \times \frac{\text { days }}{\text { year }}-r_{b} \times \frac{\text { days }}{\text { year }}}{1+r_{b} \times \frac{\text { days }}{\text { year }}}
$$

gde je:

FS forward swap cena

$F X_{f}$ kursna razlika za period u budućnosti

$F X_{s}$ spot kursna razlika

$r_{v}$ kamatna stopa za varijabilnu valutu

$r_{b}$ kamatna stopa za osnovnu valutu
Forward swap (forvard/terminski svop) omogućava eksploataciju razlike u kamatnim stopama koje se mogu ostvariti u različitim valutama. Ako se očekuje da će se razlika smanjiti (tako što će ili kamatna stopa po osnovnoj valuti porasti, ili ona koja se odnosi na varijabilnu valutu opasti), može se spekulativno kupiti osnovna valuta sada i ući u ugovor o njenoj prodaji u budućnosti. Neto efekat ove transakcije je zajam u onsovnoj valuti i simultani depozit u varijabilnoj valuti.

Iz gore navedene relacije proističe da, ako su kamatne stope $u$ varijabilnoj valuti više nego one koje se odnose na osnovnu valutu, forvard kursna razlika će biti viša nego spot i obratno. Logika iza ove dinamike je da, ako se zameni valuta koja ostvaruje višu kamatu za onu koja nosi niže kamate sada i novac se stavi na štednju, ostvareni profit bi bio niži. Nasuprot tome, ako se osnovna valuta kupi po ugovoru sa izvršenjem u budućnosti, i dalje je na raspolaganju varijabilna valuta koja se može položiti na štednju po višoj kamati do isteka ugovora. Da bi se osiguralo da je irelevantno koju će opciju investitori uzeti, forvard kursne razlike moraju da budu više, da bi kompenzovale niže kamatne stope. U ovom slučaju kažemo da je osnovna valuta " $u$ premiji". Ako su pak kamatne stope koje važe za varijabilnu valutu niže nego one za osnovnu valutu, važi suprotno, tj. osnovna valuta je "u diskontu" pa je forvard kursna razlika niža nego spot (Kožul, 2011).

Prethodne diskusije jasno ukazuju na važnost kamatnih stopa za FX tržište. Kako USD igra glavnu ulogu u velikom procentu internacionalnih transakcija, direktno utiče na dinamiku njihovih procena. Ukratko, iako mnogi faktori utiču na kursne razlike, svi su direktno vezani za trgovinske veze između zemalja učesnica (Branson 1983). Neki od njih su razmatrani u daljem tekstu.

\section{Razlike u inflaciji}

Uopšteno, duži periodi niske inflacije imaju pozitivan uticaj na vrednost valute, jer joj se povećava kupovna moć u odnosu na druge valute. Kako niska inflacija sprečava opadanje vrednosti investicija tokom vremena, obično dovodi do nižih kamatnih stopa. Niska inflacija 
value is affected not only by the fluctuations in the exchange rate between the two currencies, but also by the domestic interest rates, it is calculated as the ratio of variable and base currencies that would be available on the future date if they were both placed on deposit at their respective interest rates, i.e.:

$$
F X_{f}=F X_{s} \times \frac{1+r_{v} \times \frac{\text { days }}{\text { year }}}{1+r_{b} \times \frac{\text { days }}{\text { year }}}
$$

where:

$F X_{f}$ is the forward exchange rate

$F X_{s}$ is the spot exchange rate

$r_{v}$ is the interest rate applicable to variable currency

$r_{b}$ is the interest rate applicable to base currency

\section{Forward Cross-currency Swaps}

As can be seen from the above, forward cross-currency transactions allow the counterparties to take a view on interest rates in the two currencies involved in the exchange, without actually participating in the interest rate market. A commonly used alternative is to actually buy/sell one currency now (at spot rate) and reverse the transaction by selling/buying back the same currency at a forward rate. This is known as forward swap. As the initial swap is transacted at spot and reversed at maturity at forward exchange rate, to avoid arbitrage, the swap must be valued as the difference between the two rates, i.e.:

$$
F S=F X_{f}-F X_{s}=F X_{s} \times \frac{r_{v} \times \frac{\text { days }}{\text { year }}-r_{b} \times \frac{\text { days }}{\text { year }}}{1+r_{b} \times \frac{\text { days }}{\text { year }}}
$$

where:

FS is the forward swap price

$F X_{f}$ is the forward exchange rate

$F X_{s}$ is the spot exchange rate

$r_{v}$ is the interest rate applicable to variable currency

$r_{b}$ is the interest rate applicable to base currency

The forward swap enables traders to exploit interest rate differential between the two currencies. If they expect the gap to narrow (either the base currency interest rate rises or the variable currency interest rate falls), they will speculate by buying the base currency now and selling it forward. The net effect of this transaction is borrowing in base currency and depositing in variable currency.

From the equation above, it follows that if the variable currency interest rates are higher than those offered for base currency, the forward exchange rate will be higher than the spot, and vice versa. The logic behind this pricing is that, if we exchange higher-interest variable currency into lower-interest base currency at spot and place the amount on deposit, we would earn lower interest. However, if we buy the base currency forward, we are left with the original variable currency that can be invested and higher interest rate until settlement. To make investors indifferent as to which path they would take, the forward rates have to be higher to compensate for low interest rate. In this case, the base currency is said to be "at premium". If the variable currency interest rates are lower than base currency rates, the opposite is true; i.e., the base currency is "at discount" and the forward rate is lower than the spot (Kožul, 2011).

The discussions above clearly demonstrate the importance of interest rates in the FX market. As USD plays the key role in the large proportion of trades executed internationally, it directly affects the dynamics of their pricing. In sum, while numerous factors determine exchange rates, all are related to the trading relationship between participating countries (Branson 1983). Some of these are discussed below.

\section{Differentials in Inflation}

Generally, a consistently lower inflation rate would have a positive effect on the currency value, as its purchasing power increases relative to other currencies. As low inflation ensures that the value of investment does not depreciate over time, it typically results in lower interest rates. Lower inflation also signals health of economy, making the country attractive to foreign investors, thus increasing demand and the exchange rate further.

\section{Differentials in Interest Rates}

As previously noted, interest rates, inflation and exchange rates are highly correlated (Kožul, 2012a). Hence, by manipulating interest 
je takođe signal zdravlja ekonomije države, pa je čini atraktivnom za strane investitore, što povećava zahtev za valutom pa tako i kursnu razliku.

\section{Razlike u kamatnim stopama}

Kao što je ranije rečeno, kamatna stopa, inflacija i kursna razlika su usko povezane (Kožul, 2012a). Tako da manipulacijom kamatnih stopa, centralna banka može direktno da utiče na vrednost kako inflacije tako i kursne razlike, što menja relativnu vrednost valute na internacionalnom tržištu. Kad su domaće kamatne stope visoke, to podstiče štednju i investicije, omogućavajući veći prihod u odnosu na druge države. Zbog toga više kamatne stope privlače strani kapital i dovode do porasta kursne razlike. Sa druge strane, one rezultiraju u smanjenju potrošnje, jer je prihod od investicija i štednje relativno visok. Takođe, efekat visokih interesnih stopa je ublažen inflacijom, koja umanjuje vrednost dugoročnih ugovora.

\section{Trgovinski bilans}

Trgovinski bilans je ukupna suma izvoza i uvoza između države i njenih trgovinskih partnera, $i$ obuhvata sve transakcije vezane za robu, usluge, kamate i dividende. Kada država uvozi više nego što izvozi, dolazi do deficita u državnom budžetu, jer je potrošnja na spoljnu trgovinu veća nego priliv sredstava. To obično uslovljava pozajmljivanje kapitala iz inostranih izvora da bi se kompenzovao deficit. Kao rezultat, država ima višak domaće valute, dok ima potrebu za većom količinom stranih valuta nego što je ostvareno kroz izvoz. Ova dodatna tražnja za stranim valutama dovodi do pada kursne razlike, što povlači pad vrednosti domaćih proizvoda i usluga. Balans se ponovo uspostavlja kada domaća roba postane dovoljno jeftina i tako konkurentna na stranom tržištu, a i dostupna domaćim potrošačima (Eichenbaum \& Evans, 1993).

\section{Javni dug}

Javni dug je uobičajen izvor finansiranja vlade, a ostvareni prihodi se ulažu u velike projekte javnog sektora, kao i za podmirivanje troškova državnog aparata, kao što su razvoj infrastrukture, obrazovanje, zdravstvo, obezbeđenje, itd. Iako takve inicijative podstiču domaću ekonomiju, jer stvaraju radna mesta i poboljšavaju životni standard, strani investitori su retko zainteresovani za ulaganja u države u kojima je javni dug visok, jer to dovodi do rasta inflacije. Stoga, ne samo što visok javni dug čini neizvršenje verovatnijim, već i visoka inflacija umanjuje buduću vrednost domaće valute, čineći je neatraktivnom za investitore.

Pre početka finansijske krize 2008. godine, vlade zapadnih zemalja su mogle lako da dođu do kapitala emitovanjem državnih obveznica. Iako je dug vlade smatran sigurnom investicijom pa je donosio niže prihode nego rizičniji oblici ulaganja, državne obveznice su bile atraktivne za investitore. Zbog toga, ako bi došlo do deficita u budžetu po isteku obveznice, vlada bi mogla da ga pokrije izdavanjem nove.

Zbog krize, ovaj oblik finansiranja je postao mnogo teži, jer su mnoge velike korporacije i investicione firme bankrotirale, a i neke države su bile pred stečajem. Ova situacija je zahtevala nove mere, pa su vlade nekih država bile prinuđene da štampaju novac, što je umanjilo vrednost date valute. Osim toga, ako vlada nije u stanju da servisira deficit kroz domaće kanale, mora to činiti većim plasmanom finansijskih produkata na internacionalno tržište, što umanjuje njihovu vrednost. Takav oblik finansiranja je skup za vlade i može da dovede do pogoršanja deficita, i tako poveća rizik neizvršenja dužničkih obaveza. To takođe negativno utiče na kreditni rejting države, kao što su oni koje izdaje Moody's ili Standard \& Poor's (Kožul, 2012b), kao još jedan važan faktor u vrednosti deviznog kursa.

\section{Trgovinski uslovi}

Kada država ima dobru reputaciju na međunarodnom nivou i kvalitet njene robe $\mathrm{i}$ usluga može da opravda visoke izvozne cene, njihova vrednost $\mathrm{u}$ odnosu na uvoz raste, dovodeći do pozitivnog trgovinskog bilansa i povoljnih trgovinskih uslova. Veći obim izvoza stvara veću potražnju za valutom te države, pa joj i vrednost raste. To direktno utiče na porast kursne razlike. 
rates, central banks exert influence over both inflation and exchange rates, affecting the relative currency value in the international markets. When domestic interest rates are high, they prompt saving and investment, offering lenders higher return relative to other countries. Therefore, higher interest rates attract foreign capital and cause the exchange rate to rise. On the other hand, they tend to reduce spending, as interest earned on savings and deposits is relatively high. In addition, the effect of higher interest rates is mitigated by high inflation, as it depreciates the real value of long-term contracts.

\section{Trade Balance}

Trade balance is the balance of imports and exports between a country and its trading partners, and pertains to all transactions related to goods, services, interest and dividends. When a country imports more than it exports, a deficit in the current account occurs, as the country is spending more on foreign trade than it is earning. This typically necessitates borrowing capital from foreign sources to make up the deficit. Consequently, the country has surplus of its own currency, while requiring more foreign currency than it receives through sales of exports. The excess demand for foreign currency lowers the country's exchange rate, resulting in declining cost of domestic goods and services. The balance is re-established when the prices of domestic products become sufficiently low to once again become competitive in foreign markets and accessible to domestic consumers (Eichenbaum, \& Evans, 1993).

\section{Public Debt}

Public debt is a common source of government financing, whereby the obtained funds are utilized for large-scale public sector projects and other governmental expenditure, such as infrastructure development, education, healthcare, security, etc. While such initiatives stimulate the domestic economy, as they create jobs and improve quality of life, foreign investors are rarely attracted to nations with large public deficits, as debt encourages inflation. Thus, not only large debt increases the likelihood of default, but high inflation will also depreciate the future value of domestic currency, making it unattractive for investors.

Prior to the financial crisis of 2008, governments of Western countries could easily issue bonds to finance their spending. While government debt was deemed safe and yielded lower interest than more risky assets, they were sufficiently attractive to the investors. Consequently, if there was a shortfall at the maturity of a government bond, this could be covered by issuing a new one.

Following the crisis, this mode of financing became increasingly difficult, as many large corporations and investment institutions filed for bankruptcy and many countries were also at risk of default. This called for different measures, with some governments resorting to printing money, depreciating the value of their currency. Moreover, if a government is not able to service its deficit through domestic means, it must increase the supply of securities in the international markets, which lowers their prices. Such financing is expensive for governments and may worsen their debt exposure, increasing risk of default. This also adversely affects the country's credit rating determined by Moody's or Standard \& Poor's (Kožul, 2012b), as another highly important determinant of its exchange rate.

\section{Terms of Trade}

When the country has high standing in the global community and the quality of its goods and services can command greater export prices, their value relative to those of imports improves, creating positive payment balance and favourable terms of trade. Greater export volume results in increased demand for the country's currency, whereby its value appreciates. This has a direct and positive effect on the exchange rate.

\section{Political Stability and Economic Performance}

While risky assets typically generate higher returns, to compensate investors for accepting such risk, most are drawn to politically and economically stable countries. As such countries attract foreign investors, they withdraw their capital from other countries perceived as riskier, 


\section{Politička stabilnost i ekonomska situacija}

Iako rizičniji oblici ulaganja dovode do većeg prihoda da bi kompenzovali investitorima prihvatanje dodatnog rizika, većina je ipak više motivisana da ulaže $u$ politički stabilne države u kojima je povoljna ekonomska situacija. Kako takve države privlače strane investitore, oni povlače svoj kapital iz zemalja koje se smatraju rizičnijim, i tako dodatno povećavaju ovaj disparitet. To dovodi do porasta vrednosti date valute u odnosu na druge i pozitivno utiče na kursnu razliku (Hopper, 1997).

\section{Uloga kamatnih stopa u SAD u globalnoj ekonomiji}

S obzirom na to da je USD valuta u kojoj je podmirena većina međunarodnih ugovora, $\mathrm{i} u$ odnosu na koju su date kursne razlike za sve svetske valute, ona igra važnu ulogu u svim gore navedenim procesima. Iako je uvođenje EUR stvorilo potencijal za nastanak nove svetske valute, ovo se očekivanje nikada nije ostvarilo i kriza koja je uticala na mnoge članice EU je imala suprotan efekat. Ovaj trend se ogleda u jačanju USD u odnosu na EUR, i njegovom porastu za $19 \%$ u prethodnoj godini. Porast kamatnih stopa takođe signalizira oporavak američke ekonomije, što motiviše strane investitore da ulažu kapital u SAD. Iako će cena američkog izvoza da poraste, ovaj efekat je umanjen činjenicom da većina korporacija posluje na globalnom nivou i tako ostvaruje veći deo dohotka iz internacionalnih izvora. Uz to, velike proizvodne kompanije uglavnom lociraju svoje kapacitete u zemljama gde su radna snaga i izvorni resursi jeftini, tako da će porast vrednosti dolara njih učiniti još profitabilnijim. Zbog toga se, u širem smislu, za SAD, skoro povećanje kamatnih stopa čini pozitivnim. Ipak, kako je dinamika domaće i globalne ekonomije vrlo kompleksna, nije moguće doneti tako jednostavan zaključak, i vreme će pokazati kakve će posledice ovaj porast imati u praksi.

Globalno, slika je takođe višestrana, jer će oni koji uglavnom zavise od kamate na investicije denominirane u USD ostvariti veću dobit, dok će države sa velikim dugom imati teškoća da ga otplate. Uz to, kako USD postaje sve atraktivniji za strane investitore, on će povući kapital iz drugih država, i tako im otežati pristup izvorima finansiranja. Ovo će naročito pogoditi države u razvoju koje su najveći nosioci duga denominiranog u USD, ali će uticati na sve devizne kurseve.

Za potencijalne investitore, dolar možda ponovo izgleda kao bezbedno utočište. Ipak, mnogi analitičari su mišljenja da su zlato i srebro, kao i neki drugi plemeniti metali, relativno potcenjeni i da će dugoročno održati visoku vrednost, je su njihove prirodne rezerve ograničene, dok su sve svetske valute podložne prethodno razmatranim uticajima.

\section{Zaključak}

Kursna razlika za bilo koju valutu, pa tako i USD, jeste znak njene relativne vrednosti i stoga privlačnosti date države za investitore. Dok je istorijski većina finansijskih modela podrazumevala da će kamatne stope ostati pozitivne, skore promene u globalnoj ekonomiji su dovele $\mathrm{u}$ pitanje ovu pretpostavku. Takođe, pad cene nafte i znatna volatilnost svetskih finansijskih tržišta uveliko otežava davanje bilo kakvih procena o prevalentnom efektu porasta kamatnih stopa u SAD. Vlasnici investicionih portfolija denominiranih u USD će ostvariti veću dobit na njihov ulog, dok će izvoznici morati da kompenzuju veću vrednost njihove robe i usluga povećanjem produktivnosti ili relokacijom proizvodnih kapaciteta u države gde su resursi jeftiniji. Zemlje u razvoju će biti najviše ugrožene, jer su nosioci velikog procenta duga denominiranog u USD, koji će biti sve teže finansirati. Konačno, EUR koji je nakon usvajanja bio smatran jakim kandidatom za alternativnu svetsku valutu izgubio je vrednost u odnosu na USD, potvrđujući da će dolar verovatno ostati sigurno utočište za većinu internacionalnih investitora, uz tradicionalno visoko vrednovane plemenite metale. 
further increasing this disparity. This improves the value of currency relative to others, having positive effect on the exchange rate (Hopper, 1997).

\section{The Role of US Interest Rates in Global Economy}

Given that USD is the currency in which most international contracts are settled and exchange rates quoted, it implicitly plays a role in all dynamics discussed above. While introduction of Euro offered the potential for having another major world currency, this expectation has never materialized and the crisis that has affected many EU countries has had an opposite effect. This is evident in the growing value of USD relative to EUR, which has risen by over $19 \%$ in the last year. Increased interest rates also signal that the US economy is improving, motivating foreign investors to place their capital there. While the cost of US exports will inevitably increase, this effect is mitigated for most corporations that operate at the global level and draw significant proportion of their profits from international sources. In addition, large manufacturers tend to have their production facilities in countries where labour and resources are cheap, and increasing value of dollar will make them even more affordable. Thus, overall, for the US, the recent increase in interest rates seems to be positive. However, the dynamics of domestic and global economy are so complex, that no such simple conclusion can ever be drawn and time will tell how this recent rate increase will play out.

Globally, the picture is also mixed, as those largely depending on the interest on their USDdenominated investments will see increase in their returns, while countries with large debt will struggle to pay it off. In addition, as USD becomes more attractive to foreign investors, they will withdraw their capital from elsewhere, making it more challenging for these countries to raise their funds. This will particularly affect emerging economies that hold most of USD-denominated debt, but will also affect all exchange rates.

For those looking to invest, dollar may once again seem as a safe haven. Still, many market analysts feel that gold and silver, as well as some other precious metals, are relatively underpriced and will continue to hold high value in the long-term, given that their supply is limited, while all currencies are affected by the dynamics discussed above.

\section{Conclusion}

The exchange rate of any currency, and thus USD, is a sign of its relative value and thus attractiveness of investments in that country. While historically most pricing models assumed that interest rates will remain positive, recent changes in the global economy have challenged this view. Moreover, with falling oil prices and significant volatility in the world financial markets, it is difficult to offer any definitive predictions regarding the effects that raising US interest rates will have overall. Those with strong USD-denominated investment portfolios will see growing return on their capital, while exporters will need to compensate for the greater value of their goods and services by increasing productivity or outsourcing to countries where resources can be obtained more cheaply. Emerging market economies are posited to be affected most adversely, as they hold the largest proportion of their debt in USD, which will become increasingly difficult to finance. Finally, EUR that was following its adoption posited to be a strong candidate for an alternative major world currency has lost its value relative to the USD, suggesting that the latter will likely remain safe haven for most international investors, along with traditionally held commodities, such as precious metals. 


\section{Literatura / References}

1. Bilson, J. (1978). The Monetary Approach to the Exchange Rate - Some Empirical Evidence. IMF Staff Papers, 25, 48-75.

2. Branson, W. (1983). Macroeconomic Determinants of Real Exchange Rate Risks. In R. J. Herring (Ed.), Managing Foreign Exchange Risk. Cambridge, UK: Cambridge UniversityPress.

3. Eichenbaum, M., \& Evans, C. (1993). Some Empirical Evidence on the Effects of Monetary Policy Shocks on Exchange Rates. NBER Working Paper 4271.
4. Hopper, G. P. (1997). What Determines the Exchange Rate: Economic Factors or Market Sentiment? Business Review, Sep/Oct, 17-29.

5. Kožul, N. (2011). Mastering Investment Banking Securities: A Practical Guide to Structures, Products, Pricing and Calculations. Upper Saddle River, NJ: Pearson Education.

6. Kožul, N. (2012a). The relationship between nominal interest rates, real rates and inflation term structure. Bankarstvo, 41 (3), 10-21. 
7. Kožul, N. (2012b). Sovereign and corporate credit rating. Bankarstvo, 41 (1), 36-55.

8. Patel P. J., Patel N. J., \& Patel A. R. (2014). Factors affecting Currency Exchange Rate, Economical Formulas and Prediction Models. International Journal of Application or Innovation in Engineering \& Management (IJAIEM), 3 (3), 53-56. 